\title{
Foot Print of Macro Fungi in The Coastal Forest of Bama, Baluran National Park, East Java
}

\author{
Sri Rahayu' ${ }^{1}$, Annisa Wulan Agus Utami², Cahyo Nugroho², Endah Yuliawati Permata Sari², Kusuma \\ Wardani Lydia Puspita Sari², Maghfirah Idzati Aulia², and Noor Adryan Ilsan ${ }^{3}$ \\ ${ }^{1}$ Biology Department, Faculty of Mathematics and Natural Sciences, Universitas Negeri Jakarta, Indonesia \\ ${ }^{2}$ Biology Education Department, Faculty of Mathematics and Natural Sciences, Universitas Negeri Jakarta, \\ Indonesia \\ ${ }^{3}$ International PhD programing Medicine, College of Medicine, Taipei Medical University, Taiwan
}

Corresponding author: srirahayu@unj.ac.id

\begin{abstract}
Baluran National Park, West Java, as one of the conservation sites in Indonesia, has the attraction of the varied types of ecosystems, including fungi. This study aimed to analyze the diversity of fungi in Bama Coastal Forest, Baluran National Park. The method was explorative with plot purposive sampling technique. Parameters in this study include abundance, dominance, and diversity of fungi enriched with physical parameters of humidity and temperature. The fungi were documented and macroscopically observed. Data were analyzed using the abundance index, dominance index, and diversity index. This research identified 18 types of macrofungi in Bama Coastal forest, Baluran National Park East Java including Ganoderma, $s p$, Hexagonia tenuis, Trametes hirsute, Phellinus sp.1 and sp.2, Ganoderma applanatum, Phellinus igniarius, Pycnoporus cinnabarinus, Daedalea quercina, Tyromyces chioneus, Microporus xanthopus, Calvatia sp., Irpex lacteus, Trichaptum sp., Lentinus sp. Poria corticola, Tyromyces sp., and Lichemomphalia sp. One fungi species (Ganoderma sp.) has the highest abundance index (27.62). The Medium abundance index was found in three species (Hexagonia tenuis, Tyromyces chioneus, Tyromyces sp.) while the rest fungi were in low abundance index. Dominance index of all fungi species identified in Bama was in low category $(\mathrm{D}<0.5)$ with medium diversity (2.30). It can be concluded that the diversity of microfungi in the coastal forest of Bama, Baluran National park was a distribution medium of individual of each species and medium community stability. Environmental conditions in the Bama Coast Forest with $93 \%$ humidity and an average air temperature of 26-27oC could support for the fungi to grow quite well.
\end{abstract}

Keywords: Biodiversity, fungi, Bama, Baluran.

\section{Introduction}

Baluran National Park (TNB) is one of the very interesting national park areas with a number types of ecosystems. Nine types of ecosystems exist in the area include: evergreen, evergreen, savannah forests, mountain forests, coastal forests, mangrove forests, natural teak forests, artificial teak forests, and ecotones. These ecosystems lead to high biodiversity of flora and fauna in the area. One of the biodiversity found is fungi. Fungi generally occupy various types of habitats namely soil, wood, litter, animal waste and so on (Annisa et al., 2017). Fungi is one of the uniqueness that enriches the diversity of species of living things. Several types of fungi have been widely used by humans as food ingredients (Brown et al., 2019) due to their nutritional values needed such as protein, carbohydrate and fat. Other species also contribute to human health and being used as modern medicine (Langdon et al., 2019; Xu et al., 2020). Furthermore, they also make use 
of fungi as animal feed (Nair et al., 2018; da Silva et al., 2017; Sukmawati et al., 2018). Ecological function Macrophages are part of a group of fungi or fungi that have fruit bodies and can be observed with the eye directly. macroscopic fungi or macrophages are the main group of lignocellulosic degrading organisms on nature because they are able to produce lignocellulosic degrading enzymes such as cellulase, ligninase, and hemicellulase, so that the material cycle can continue or is commonly referred to as a decomposer function (Fernandes \& Kennedy, 2018; Hiscox et al., 2018; Hobbie et al., 2020). This last discussed point of fungi placed their importance on many land area including forest and coast.

Several studies have revealed the importance of macro fungi in every land altitude from high mountain (Kotilínek et al., 2018; Lazarević \& Menkis, 2020) to low land (Roy et al., 2016; Oehl et al., 2020). It is estimated of 69,000 species of fungi (macro and micro) were identified. As many as 200,000 species from 1.5 million species of mushrooms are estimated to be found in Indonesia. Many fungi biodiversity has been documented in many national park around Indonesia such as kamojang (Arko, 2017), Gunung Halimun (Putir, 2019) and many more. Information about fungi on Baluran revealed the diversity of endophytic one on evergreen area (Murdiyah, 2017). Other finding investigate the macroscopic diversity of fungi on several area in Baluran (evergreen, teak forest, hilly primary forest and lowland primary forest) with highest dominance index found on teak forest. Bama coastal forest as part of lowland primary forest. Marasmius sp. 7 was identified as the most abundance fungi in lowland forest (Wati et al., 2019). Unfortunalety, the research was done in 2013 and have just published in 2019. Yearly evaluation and identification of fungi richness is not continued. Thus, latest and update study would best being done since rapid rate of decline in biodiversity either by natural processes or due to human activity keep on going. Occurrence of species diversity information would best reflect a sound and metric for taking action of planning and evaluating conservation (Lelli et al., 2020).

The study base was done on investigating the foot print of macro fungi in coastal forest of Bama, Baluran National Park, East Java. The findings would determine the role of fungi in the environment of Bama in order to add information and insights about the types of fungi found in Indonesia and the matric of diversity.

\section{Material and Method}

The research method used was explorative with plot purposive sampling technique on the coastal forest of Bama National Park, East Java. The materials observed in this study were fungi and substrates along the Bama Coastal Forest, Baluran National Park to be identified and analyzed (Irawati and Christia, 2016). Parameters in this study include abundance, dominance, and diversity of fungi enriched with physical parameters of humidity and temperature. The fungi found were documented and macroscopically observed. Data were analyzed using abundance, dominance and diversity index. 
Abundance index was analyzed with Krebs (Enrich et al., 2020)

Relative abundance $=\frac{n i}{N} \times 100 \%$

$\mathrm{ni}=$ number of individual types

$\mathrm{N}=$ total number of individuals

Interprestation of abundance index was measured using criteria on table 1:

Table 1. Abundace index criteria

\begin{tabular}{ll}
\hline Abundance Index Value & Abundance Index Criteria \\
\hline 0 & none \\
$1-10$ & low \\
$11-20$ & medium \\
$>20$ & high \\
\hline
\end{tabular}

Dominance index was quantified based on Simpson

$\mathrm{ni}=$ number of individual types

$$
\mathrm{C}=\sum \frac{n i^{2}}{N^{2}}
$$

$\mathrm{N}=$ total number of individuals

Interprestation of dominance index was measured using criteria on table 2 :

Table 2. Dominance index criteria

\begin{tabular}{ll}
\hline Dominance index value & Dominance index criteria \\
\hline $0<$ D 0.5 & low \\
$0.5<$ D 0.75 & medium \\
$0,75<$ D 1.00 & high \\
\hline
\end{tabular}

Diversity index was measured by Shannon-Wiener

$$
\mathrm{H}^{\prime}=-\sum \frac{n i}{N} \ln \frac{n i}{N}
$$

$\mathrm{H}^{\prime}=$ Species diversityKeanekaragaman Spesies

$\mathrm{ni}=$ number of individual types

$\mathrm{N}=$ total number of individuals 
Interprestation was done based on the table 3:

Tabel 3. Diversity Index criteria

\begin{tabular}{ll}
\hline Diversity index value & Diversity index criteria \\
\hline$>3$ & $\begin{array}{l}\text { High diversity, high distribution of individual of each } \\
\text { species, high community stability }\end{array}$ \\
& $\begin{array}{l}\text { Medium diversity, medium distribution of individual of } \\
\text { each species, medium community stability }\end{array}$ \\
& Low diversity, lowdistribution of individual of each species, \\
& low community stability
\end{tabular}

\section{Results and Discussion}

\subsection{Results}

Based on research results in the Bama National Park Baluran forest, 18 species of fungi which belong to 14 genus with an ambient temperature of $26-27^{\circ} \mathrm{C}$ and an average humidity of 93\% were documented. Genus found were Ganoderma, Hexagonia, Trametes, Phellinus, Pycnopurus, Daedalea, Tyromyces, Microporus, Calvatia, Irpex, Trichaptum, Lentinus, Poria and Lichenomphalia. Identification result of fungi was seen on the following table 4:

Table 4. Fungi Identification of Bama National Park

\begin{tabular}{|c|c|c|c|c|c|}
\hline Spesies & Genus & Family & Order & Class & Phyllum \\
\hline Ganoderma sp. & Ganoderma & Ganodermataceae & Polyporales & Agaricomycetes & Basidiomycota \\
\hline $\begin{array}{l}\text { Hexagonia } \\
\text { tenuis }\end{array}$ & Hexagonia & Polyporaceae & Polyporales & Agaricomycetes & Basidiomycota \\
\hline $\begin{array}{l}\text { Trametes } \\
\text { hirsuta }\end{array}$ & Trametes & Polyporaceae & Polyporales & Agaricomycetes & Basidiomycota \\
\hline Phellinus sp. 1 & Phellinus & Hymenocataceae & Hymenochaetales & Agaricomycetes & Basidiomycota \\
\hline Phellinus sp. 2 & Phellinus & Hymenocataceae & Hymenochaetales & Agaricomycetes & Basidiomycota \\
\hline $\begin{array}{l}\text { Ganoderma } \\
\text { applanatum }\end{array}$ & Ganoderma & Ganodermataceae & Polyporales & Agaricomycetes & Basidiomycota \\
\hline $\begin{array}{l}\text { Phellinus } \\
\text { igniarius }\end{array}$ & Phellinus & Hymenocataceae & Hymenochaetales & Agaricomycetes & Basidiomycota \\
\hline $\begin{array}{l}\text { Pycnoporus } \\
\text { cinnabarinus }\end{array}$ & Pycnoporus & Polyporaceae & Polyporales & Agaricomycetes & Basidiomycota \\
\hline $\begin{array}{l}\text { Daedalea } \\
\text { quercina }\end{array}$ & Daedalea & Fomitopsidaceae & Polyporales & Agaricomycetes & Basidiomycota \\
\hline $\begin{array}{l}\text { Tyromyces } \\
\text { chioneus }\end{array}$ & Tyromyces & Polyporaceae & Polyporales & Agaricomycetes & Basidiomycota \\
\hline
\end{tabular}




\begin{tabular}{|c|c|c|c|c|c|}
\hline Spesies & Genus & Family & Order & Class & Phyllum \\
\hline $\begin{array}{l}\text { Microporus } \\
\text { xanthopus }\end{array}$ & Microporus & Polyporaceae & Polyporales & Agaricomycetes & Basidiomycota \\
\hline Calvatia sp. & Calvatia & Agaricaceae & Agaricales & Agaricomycetes & Basidiomycota \\
\hline Irpex lacteus & Irpex & Phanerochaetaceae & Polyporales & Agaricomycetes & Basidiomycota \\
\hline Trichaptum sp. & Trichaptum & Not assigned & Hymenochaetales & Agaricomycetes & Basidiomycota \\
\hline Lentinus sp. & Lentinus & Polyporaceae & Polyporales & Agaricomycetes & Basidiomycota \\
\hline Poria corticola & Poria & Polyporaceae & Polyporales & Agaricomycetes & Basidiomycota \\
\hline Tyromyces sp. & Tyromyces & Polyporaceae & Polyporales & Agaricomycetes & Basidiomycota \\
\hline $\begin{array}{l}\text { Lichenomphalia } \\
\text { sp. }\end{array}$ & $\begin{array}{l}\text { Lichenomph } \\
\text { alia }\end{array}$ & Hygroporaceae & Agaricales & Agaricomycetes & Basidiomycota \\
\hline
\end{tabular}

Macroscopic identification of the fungi found was done based on he shape and color of the fungi body, the hood type, the hood diameter, the shape of the stem, the length and diameter of the stem, the presence or absence of the ring, the lamella type, and the type of fungal volva. Macroscopic appearance of some fungi fund was describes on figure 1.
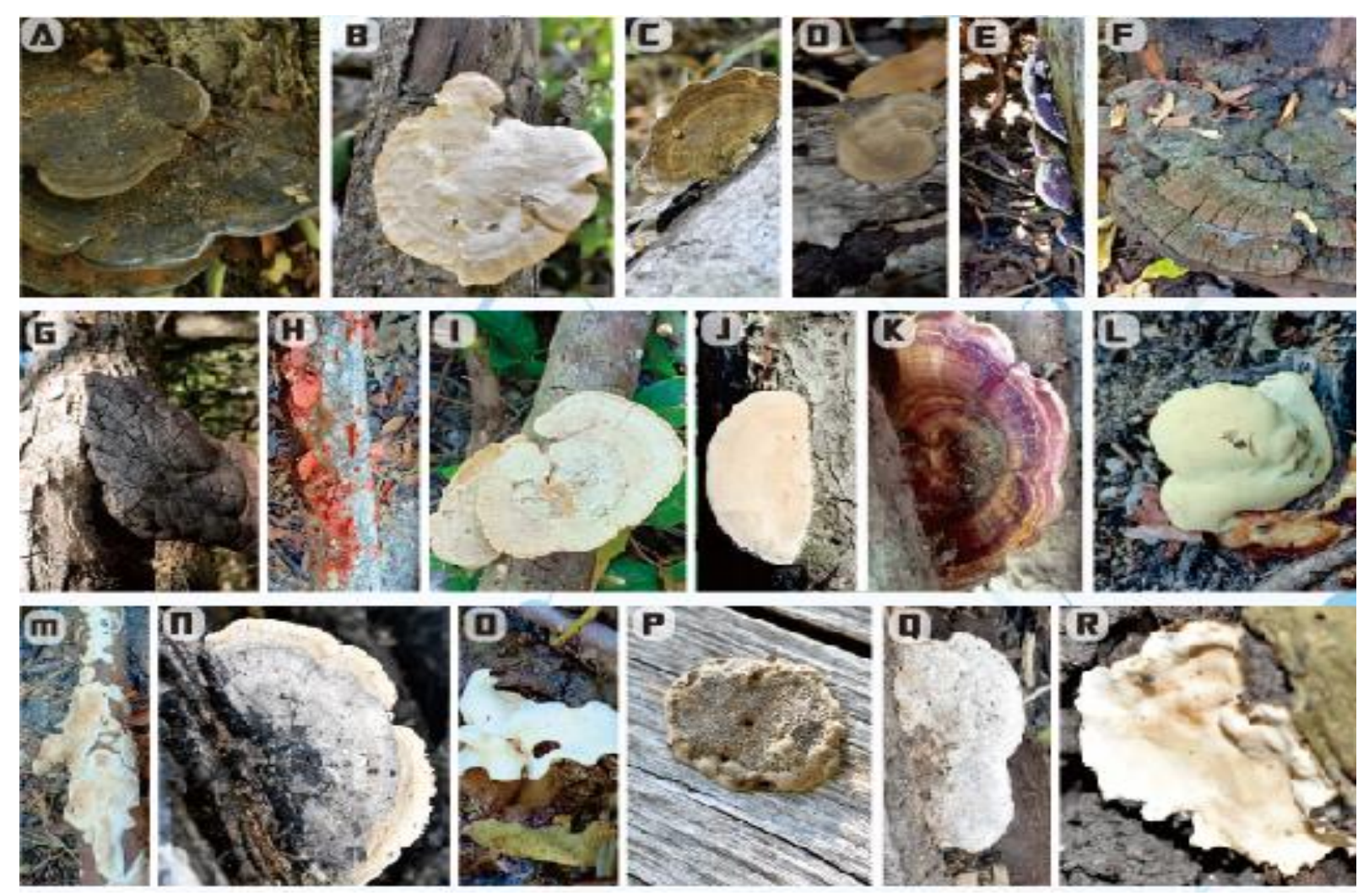
Figure 1. Macro fungi Variety in the Bama Coast Forest, Bunaken National Park, East Java. a). Ganoderma sp. b). Hexagonia tenuis. c). Trametes hirsuta d). Phellinus sp. 1 e). Phellinus sp. 2 f). Ganoderma applanatum g). Phellinus igniarius h). Pycnoporus cinnabarinus, i). Daedalea quercina, j). Tyromyces chioneus, $k$ ). Microporus xanthopus, l). Calvatia sp., M). Irpex lacteus, n). Trichaptum sp. o). Lentinus sp., P). Poria corticola, q). Tyromyces $s p$., R). Lichenomphalia $s p$

Based on analysis in abundance index, Ganoderma sp. was categorized having high abundance. Medium abundance was found in 3 species of Hexagonia tenuis, Tyromyces chioneus, Tyromyces sp. The rest species identified shown low abundance index category. Dominance index of all species were identified as low. Detail result of abundance and dominance index can be seen in table 5 .

Table 5. Abundance and dominance index of Fungi in Bama

\begin{tabular}{clll}
\hline No & \multicolumn{1}{c}{ Species } & \multicolumn{1}{c}{$\begin{array}{c}\text { Abundance } \\
\text { index }\end{array}$} & $\begin{array}{c}\text { Dominance } \\
\text { index }\end{array}$ \\
\hline $\mathbf{1}$ & Ganoderma sp. & 27.62 & 0.07628 \\
$\mathbf{2}$ & Hexagonia tenuis & 11.43 & 0.01306 \\
$\mathbf{3}$ & Trametes hirsuta & 1.90 & 0.00036 \\
$\mathbf{4}$ & Phellinus sp. 1 & 0.95 & 0.00009 \\
$\mathbf{5}$ & Phellinus sp. 2 & 5.24 & 0.00274 \\
$\mathbf{6}$ & Ganoderma applanatum & 3.81 & 0.00145 \\
$\mathbf{7}$ & Phellinus igniarius & 0.48 & 0.00002 \\
$\mathbf{8}$ & Pycnoporus cinnabarinus & 7.14 & 0.00510 \\
$\mathbf{9}$ & Daedalea quercina & 0.48 & 0.00002 \\
$\mathbf{1 0}$ & Tyromyces chioneus & 12.38 & 0.01533 \\
$\mathbf{1 1}$ & Microporus xanthopus & 2.38 & 0.00057 \\
$\mathbf{1 2}$ & Calvatia sp. & 0.48 & 0.00002 \\
$\mathbf{1 3}$ & Irpex lacteus & 1.90 & 0.00036 \\
$\mathbf{1 4}$ & Trichaptum sp. & 4.76 & 0.00227 \\
$\mathbf{1 5}$ & Lentinus sp. & 1.43 & 0.00020 \\
$\mathbf{1 6}$ & Poria corticola & 2.86 & 0.00082 \\
$\mathbf{1 7}$ & Tyromyces sp. & 14.29 & 0.02041 \\
$\mathbf{1 8}$ & Lichenomphalia sp. & 0.48 & 0.00002 \\
\hline
\end{tabular}

Analysis in diversity index revealed that macro fungi biodiversity in Bama Coastal Forest, Baluran National Park, East Java fall in 2.30 index value. Means that fungi in Bama was in medium diversity with, medium distribution of individual of each species and medium community stability.

\subsection{Discussion}

Exploration on the diversity of fungi in the Bama Coastal area of Baluran National Park needs to be done as an effort to invent, manage and conserve the potential of existing biological resources. In forest ecosystems, fungi might take important function as decomposers of organic matter, form mycorrhizal associations with trees, occur as 
parasites or pathogens and are food resources for various organisms. They also shows dominance function of microbes as decomposer (López-Mondéjar, 2018).

Total of 18 types and 14 genera of macroscopic fungi were collected from Bama National Park which all belong to Basidiomycota. Basidiomycota divion is one of the most abundance fungi instead of Ascomycota which can be found in many field (Gorobets et al., 2018). Every fungi has different survival which decided by environment factors as well as subtrate. Diverse and abundance substrate supply would determined the fungi diversity (Runnel \& Locmus, 2017). During the observation process, many fungi are found and grow in clusters on wood and dead branches. Majority of woodrotting fungi preferred to grow during hot wet season and under open canopy where the substrate is exposed to sunlight (Chuzho et al., 2019). Dead tree trunks will rot and merge with the ground. The presence of fungus will accelerate the weathering process of dead plant stems, by sticking and living on the dead tree trunk to take nutrients and nutrients that are still available on the trunk of the dead tree (Heillman-Claussen, 2015). All fungi that play a role in the weathering process are saprophytes, which are able to change the composition of dead organic matter. Most saprofit fungi produce hydrolase enzymes (Ökmen et al., 2019) in food substrate that function to decompose complex molecules. The role of fungi in the weathering process can be one way to balance the ecosystem in the Bama Coast Forest environment.

The most abundant and dominant type of mushroom is Ganoderma sp. This shows that the fungus grow well in these locations and have ecological functions. Ganoderma sp. can dominate the area because it is supported by environmental factors, including water, light, and humidity (Adarsh, 2019). This species also have the potential to be developed as medicinal fungi (Khastini et al., 2017). This fiindings is different with previous research that revealed Marasmius spp as the most abundance type on low land forest of Bama (Wati et al., 2019). Differences might be also occur since climate has changed and also environment changes which create different habitat condition (Asemaninejad et al., 2018). Moreover, previous findings was expose on biggest part of Baluran low land forest, while this study focus specifically on Bama coastal forest.

Medium abundance index was found in three species fungi indentified in Bama (Hexagonia tenuis, Tyromyces chioneus, Tyromyces sp.) Diiferent result of abundance was found in Pune where hexagonia tenuis was included in the most dominance species found (Bhosale et al., 2019). The difference finding was due to different monsoon and winter climates which act as ideal conditions for the growth the development of macro-fungi (Yemul et al., 2019). The lowest abundance index was revealed in the rest of 14 fungi species found. Four species identified as the lowest abundance of 0.48 index (Phellinus igniarius, Daedalea quercina, Calvatia sp. and Lichenomphalia sp.). Phellinus sp. was already known as wood inhabiting fungi, capable of utilizing structural polymers of wood (Deshmuskh et al., 2019). Some species with low abundance index has comparable effect on sunlight exposure of area where 3 of these fungi were found. 
Based on the calculation of the macroscopic fungi species diversity index value, the Bama Coastal Forest area Baluran National Park was included in the medium category. This value explains that the area has sufficient productivity, balanced ecosystem conditions, and moderate ecological pressure. Physical condition give huge impavt on the life of fungi. They are including temperature, humidity, acidity and substrate. The best condition of macroscopic fungi to grow well will be winter and rainy season (Wang, 2017) when higher humudiy and substrate humidity are optimum. Result suggest that condition on Bama was quite good to harbour the life of fungi.

\section{Conclusion}

The research identified 18 type of macro fungi in Bama Coastal forest, Baluran National Park East Java including Ganoderma, sp, Hexagonia tenuis, Trametes hirsute, Phellinus sp.1 and sp.2, Ganoderma applanatum, Phellinus igniarius, Pycnoporus cinnabarinus, Daedalea quercina, Tyromyces chioneus, Microporus xanthopus, Calvatia sp., Irpex lacteus, Trichaptum sp., Lentinus sp. Poria corticola, Tyromyces sp., and Lichemomphalia sp. One fungi species (Ganoderma sp.) has high abundance index (27.62). Medium abundance index was found in three species (Hexagonia tenuis, Tyromyces chioneus, Tyromyces sp.) while the rest fungi were in low abundance index. Dominance index of all fungi species identified in Bama was in low category $(D<0.5)$ with medium diversity (2.30). It can be concluded that diversity of micro fungi in the coastal forest of Bama, Baluran National park was medium with medium distribution of individual of each species and medium community stability. Environmental conditions in the Bama Coast Forest was quite good to harbour the life of fungi.

\section{References}

Adarsh, C. K., Vidyasagaran, K., \& Ganesh, P. N. (2019). The diversity and distribution of polypores (Basidiomycota: Aphyllophorales) in wet evergreen and shola forests of Silent Valley National Park, southern Western Ghats, India, with three new records.Journal of Threatened Taxa,11(7), 13886-13909. https://doi.org/ 10.11609/jott.3856.11.7.13886-13909

Annisa, I., Ekamawanti, H. A., \& Wahdina. (2017). Keanekaragaman jenis jamur makroskopis di Arboretum Sylva Universitas Tanjungpura. Jurnal Hutan Lestari, 5(4), 969-977

Arko, P. F., Marzuki, B. M., \& Kusmoro, J. (2017). The inventory of edible mushroom in Kamojang Nature Reserve and Nature Park, West Java, Indonesia. Biodiversitas Journal of Biological Diversity, 18(2), 530-540. https://doi.org/10.13057/ biodiv/d180213

Asemaninejad, A., Thorn, R. G., Branfireun, B. A., \& Lindo, Z. (2018). Climate change favours specific fungal communities in boreal peatlands. Soil Biology and Biochemistry, 120, 28-36. https://doi.org/10.1016/j.soilbio.2018.01.029 
Bhosale, A. K., Kadam, V., Bankar, P., Shitole, S., Chandankar, S., Wagh, S., \& Kanade, M. B. (2019). Checklist of Macro-Fungi from Baramati Area of Pune District, MS, India. Int. J. Curr. Microbiol. App. Sci, 8(7), 2187-2192. https://doi.org/ 10.20546/ijcmas.2019.807.265

Brown, M. (2019). Yi Ethnomycology: Wild Mushroom Knowledge and Use in Yunnan, China. Journal of Ethnobiology,39(1), 131-157. https://doi.org/10.2993/02780771-39.1.131

Chuzho, K., \& Dkhar, M. S. (2019). Ecological Determinants of Wood-Rotting Fungal Diversity and First Report of Favolaschia calocera, an Invasive Species from India. Proceedings of the National Academy of Sciences, India Section B: Biological Sciences, 89(4), 1177-1188. https://doi.org/10.1007/s40011-018-1038-1

Deshmukh, S.K., Prakash, V., \& Gupta, M. K. (2019). The Genus Phellinus. Advances in Macrofungi: Diversity, Ecology and Biotechnology, 278.

Ehrich, D., Schmidt, N. M., Gauthier, G., Alisauskas, R., Angerbjörn, A., Clark, K., Solovyeva, D. V. (2019). Documenting lemming population change in the Arctic: Can we detect trends? Ambio, 786-800. https://doi.org/10.1007/s13280-019-01198-7

Fernandez, C. W., \& Kennedy, P. G. (2018). Melanization of mycorrhizal fungal necromass structures microbial decomposer communities. Journal of Ecology, 106(2), 468-479. https://doi.org/10.1111/1365-2745.12920

Gorobets, S., Gorobets, O., Kovalchuk, I., \& Yevzhyk, L. (2018). Determination of potential producers of biogenic magnetic nanoparticles among the fungi representatives of Ascomycota and Basidiomycota divisions. Innovative Biosystems and Bioengineering, 2(4), 232-245. https://doi.org/10.20535/ibb.2018.2.4.147310

Heilmann-Clausen, J., Barron, E. S., Boddy, L., Dahlberg, A., Griffith, G. W., Nordén, J., ... \& Halme, P. (2015). A fungal perspective on conservation biology. Conservation biology, 29(1), 61-68. https://doi.org/10.1111/cobi.12388

Hiscox, J., O'Leary, J., \& Boddy, L. (2018). Fungus wars: basidiomycete battles in wood decay. Studies in mycology,89, 117-124. https://doi.org/10.1016/j.simyco.2018. 02.003

Hobbie, E. A., Grandy, A. S., \& Harmon, M. E. (2020). Isotopic and compositional evidence for carbon and nitrogen dynamics during wood decomposition by saprotrophic fungi. Fungal Ecology, 45, 100915. https://doi.org/10.1016/j.funeco.2020.100915

Irawati, D. dan Christia, M. (2016). Keanekaragaman Makrofungi di Cagar Alam Gunung Ambang Sulawesi Utara Dan Peluang Potensinya. Proceeding Seminar Nasional Biodiversitas VI 
Jiang, Y., Xiao, P., Liu, Y., Wang, J., \& Li, R. (2017). Targeted deep sequencing reveals high diversity and variable dominance of bloom-forming cyanobacteria in eutrophic lakes. Harmful Algae, 64, 42-50. https://doi.org/10.1016/j.hal.2017.03.006

Khastini, R. O., Leksono, S. M., \& Ulya, A. N. A. (2017). Biodiversitas dan potensi jamur Basidiomycota di Kawasan Kasepuhan Cisungsang, Kabupaten Lebak, Banten. AlKauniyah: Journal of Biology, 10(1), 9-16. http://dx.doi.org/10.15408/kauniyah. v10i1.4513

Kotilínek, M., Hiiesalu, Inga., Kosnar, Jiri., Smilaurova, Marie., Altman, Jan., Dvorsky, Mirosalav., Kopecky, Martin., \& Dolezal, Jirf. (2017). Fungal root symbionts of highaltitude vascular plants in the Himalayas. Scientific reports, 7(1), 1-14. https://doi.org/10.1038/s41598-017-06938-x

Langdon, S., \& Pearce, C. J. (2017). The Microbial Pharmacy: FDA Approved Medicines From Fungi. Mycosynthetix, 18, 1-4.

Lazarević, J., \& Menkis, A. (2020). Fungal Diversity in the Phyllosphere of Pinus heldreichii H. Christ-An Endemic and High-Altitude Pine of the Mediterranean Region. Diversity, 12(5), 172. https://doi.org/10.3390/d12050172

Lelli, C et al. (2019). Biodiversity response to forest structure and management: Comparing species richness, conservation relevant species and functional diversity as metrics in forest conservation. Forest Ecology and Management, 432, 707-717. https://doi.org/10.1016/j.foreco.2018.09.057

López-Mondéjar, R., Brabcová, V., Štursová, M., Davidová, A., Jansa, J., Cajthaml, T., \& Baldrian, P. (2018). Decomposer food web in a deciduous forest shows high share of generalist microorganisms and importance of microbial biomass recycling. The ISME journal, 12(7), 1768-1778. https://doi.org/10.1038/s41396-018-0084-2

Murdiyah, S. (2017). Endophytic fungi of various medicinal plants collected from evergreen forest Baluran national park and its potential as laboratory manual for mycology course.JPBI (Jurnal Pendidikan Biologi Indonesia), 3(1), 64-71. https://doi.org/10.22219/jpbi.v3i1.3977

Nair, R. B., Kabir, M. M., Lennartsson, P. R., Taherzadeh, M. J., \& Horváth, I. S. (2018). Integrated process for ethanol, biogas, and edible filamentous fungi-based animal feed production from dilute phosphoric acid-pretreated wheat straw. Applied biochemistry and biotechnology, 184(1), 48-62. https://doi.org/10.1007/s12010017-2525-1

Oehl, F., Laczko, E., Oberholzer, H. R., Jansa, J., \& Egli, S. (2017). Diversity and biogeography of arbuscular mycorrhizal fungi in agricultural soils. Biology and Fertility of Soils, 53(7), 777-797. https://doi.org/ 10.1007/s00374-017-1217-x 
Ökmen, B., Bachmann, D., \& De Wit, P. J. (2019). A conserved GH17 glycosyl hydrolase from plant pathogenic Dothideomycetes releases a DAMP causing cell death in tomato. Molecular plant pathology,20(12), 1710-1721. https://doi.org/10.1111/ mpp.12872

Putir, P. E., Tanduh, Y., \& Firdara, E. K. (2019). Biodiversitas dan Identifikasi Jamur Basidiomycetes di Taman Nasional Sebangau, Kabupaten Katingan Kalimantan Tengah.Jurnal Jejaring Matematika dan Sains, 1(1), 39-43. https://doi.org/10.36873/jjms.v1i1.135

Roy, M., Schimann, H., Braga-Neto, R., Da Silva, R. A., Duque, J., Frame, D., ... \& Neves, M. A. (2016). Diversity and distribution of ectomycorrhizal fungi from Amazonian lowland white-sand forests in Brazil and French Guiana. Biotropica, 48(1), 90-100. https://doi.org/10.1111/btp.12297

Runnel, K., \& Lõhmus, A. (2017). Deadwood-rich managed forests provide insights into the old-forest association of wood-inhabiting fungi. Fungal Ecology, 27, 155-167. https://doi.org/10.1016/j.funeco.2016.09.006

da Silva, E. P., et al. (2018). Selection of fungi of the genus Aspergillus tannase producers for inclusion in animal feed. PUBVET, 12(2), 1-7.

Sukmawati, D., Saidah, N., Handayani, K. T., \& Rahayu, S. (2018). The characteristics of fungi contaminating chicken feed in Tegal, Bogor, West Java. Asian Journal of Agriculture and Biology, 6(4).

Strong, W. L. (2016). Biased richness and evenness relationships within Shannon-Wiener index values. Ecological indicators, 67, 703-713. https://doi.org/10.1016/ j.ecolind.2016.03.043

Wang, S., Guo, F., \& Chang, M. (2017). Optimum Culture Conditions for Three Macrofungi of Agaricaceae. Northern Horticulture, (10), 31.

Wati, R., Noverita, N., \& Setia, T. M. (2019). Keanekaragaman Jamur Makroskopis di Beberapa Habitat Kawasan Taman Nasional Baluran. Al-Kauniyah: Jurnal Biologi, 12(2), 171-180. http://dx.doi.org/10.15408/kauniyah.v12i2.10363

Xu, L. L., Ling, X. F., Zhao, S. J., Wang, R. F., \& Wang, Z. T. (2020). Distribution and diversity of endophytic fungi in Gentiana rigescens and cytotoxic activities. Chinese Herbal Medicines. 30(40), 30. http://doi.org/10.1016/j.chmed.2020.03.007

Yemul, N.B., Kanade, M.B. and Murumkar, C.V. (2019). Comprehensive Account of Leucophellinus hobsonii (Berk. ex Cooke) Ryvarden (Schizoporaceae) A Poroid species from Ratnagiri district of Western Ghats of India. Indian Forester, 145 (1): 48-51. https://doi.org/10.36808/if/2019/v145i1/142730 